\title{
Documenting good practices: scaling up the youth friendly health service model in Colombia
}

\author{
Silvia Huaynoca ${ }^{1 *}$, Joar Svanemyr ${ }^{2}$, Venkatraman C. Chandra-Mouli ${ }^{2}$ and Diva Jeaneth Moreno Lopez ${ }^{3}$
}

\begin{abstract}
Background: Young people make up for $24.5 \%$ of Latin America's population. Inadequate supply of specific and timely sexual and reproductive health (SRH) services and sexuality education for young people increases their risk of sexual and reproductive ill health. Colombia is one of the few countries in Latin America that has implemented and scaled up specific and differentiated health and SRH services-termed as its Youth Friendly Health Services (YFHS) Model.
\end{abstract}

Objective: To provide a systematic description of the crucial factors that facilitated and hindered the scale up process of the YFHS Model in Colombia.

Methods: A comprehensive literature search on SRH services for young people and national efforts to improve their quality of care in Colombia and neighbouring countries was carried out along with interviews with a selection of key stakeholders. The information gathered was analysed using the World Health Organization-ExpandNet framework (WHO-ExpandNet).

Results/Discussion: In 7 years (2007-2013) of the implementation of the YFHS Model in Colombia more than 800 clinics nationally have been made youth friendly. By 2013, 536 municipalities in 32 departments had YFHS, resulting in coverage of $52 \%$ of municipalities offering YHFS.

The analysis using the WHO-ExpandNet framework identified five elements that enabled the scale up process: Clear policies and implementation guidelines on YFHS, clear attributes of the user organization and resource team, establishment and implementation of an inter-sectoral and interagency strategy, identification of and support to stakeholders and advocates of YFHS, and solid monitoring and evaluation.

The elements that limited or slowed down the scale up effort were: Insufficient number of health personnel trained in youth health and SRH, a high turnover of health personnel, a decentralized health security system, inadequate supply of financial and human resources, and negative perceptions among community members about providing SRH information and services to young people.

Conclusion: Colombia's experience shows that for large-scale implementation of youth health programmes, clear policies and implementation guidelines, support from institutional leaders and authorities who become champions of YFHS, continuous training of health personnel, and inclusion of users in the design and monitoring of these services are key.

\footnotetext{
* Correspondence: shuaynoca@ippfwhr.org

${ }^{1}$ Independent Consultant, 125 Maiden Lane, 9th Floor, New York, NY 10038,

USA

Full list of author information is available at the end of the article
}

\section{Biomed Central}

(c) 2015 Huaynoca et al. Open Access This article is distributed under the terms of the Creative Commons Attribution 4.0 International License (http://creativecommons.org/licenses/by/4.0/), which permits unrestricted use, distribution, and reproduction in any medium, provided you give appropriate credit to the original author(s) and the source, provide a link to the Creative Commons license, and indicate if changes were made. The Creative Commons Public Domain Dedication waiver (http://creativecommons.org/publicdomain/zero/1.0/) applies to the data made available in this article, unless otherwise stated. 
Abstract: En América Latina los jóvenes constituyen el $24.5 \%$ de la población total. La inadecuada e inoportuna oferta de servicios de salud sexual y reproductiva (SSR) y educación sexual para jóvenes incrementa su riesgo a una inadecuada SSR. Colombia es uno de los pocos países en América Latina que ha implementado a nivel nacional servicios de SSR específicos y diferenciados para jóvenes -conocidos como Modelo de Servicios de Salud Amigables para Adolescentes y Jóvenes (SSAAJ).

Objetivos: Proporcionar una descripción sistemática de los factores cruciales que facilitaron y obstaculizaron la ampliación a escala del Modelo SSAAJ en Colombia.

Metodología: Basada en una revisión bibliográfica sobre servicios de SSR para jóvenes, esfuerzos nacionales para mejorar la atención de calidad en Colombia y países vecinos y entrevistas a aliados clave. La información recolectada fue analizada con el marco ExpandNet de la Organización Mundial de la Salud.

Resultados/Discusión: En los siete años (2007-2013) de implementación del Modelo SSAAJ mas de 800 clínicas a nivel nacional se convirtieron en amigables para jóvenes. En el 2013, 536 municipalidades en 32 departamentos tenían SSAAJ alcanzando una cobertura de $52 \%$ por municipalidad.

El análisis de la información identificó cinco elementos que facilitaron la ampliación a escala: políticas y guías claras de implementación de SSAAJ, atributos claros de la organización usuaria y del equipo de recursos, establecimiento e implementación de una estrategia interinstitucional e intersectorial, identificación de aliados y abogadores de los SSAAJ, y sólidos monitoreo y evaluación.

Los elementos que limitaron o retrasaron este esfuerzo fueron: insuficiente número del personal de salud capacitado en salud del joven y SSR, alta rotación del personal de salud, descentralizado sistema de seguro de salud, inadecuada dotación de recursos financieros y humanos, y percepciones negativas de miembros comunitarios sobre la oferta de información y acceso a servicios de SSR para jóvenes.

Conclusión: La experiencia en Colombia muestra que en la ampliación a escala de programas de salud para jóvenes son esenciales políticas de salud con claras directrices de implementación, apoyo de líderes y directivos institucionales trabajando en SSAAJ, formación continua del personal de salud e inclusión de usuarios en el diseño y supervisión de servicios.

Palabras clave: Servicios de salud amigables, salud sexual y reproductiva, ampliación a escala.

\section{Introduction}

Young people ${ }^{1}$ make up $27 \%$ of the world's population $[1,2]$ and $24.5 \%$ of Latin America's (LA) population [3]. Despite being considered a healthy group, young people are at higher risk of sexual and reproductive morbidity and mortality [4-7] and more likely to experience difficulties in obtaining specific and timely sexual and reproductive health $(\mathrm{SRH})$ services and sexuality education, limiting their ability to realize SRH benefits [8-11].

During the last few years a large number of countries have expressed a commitment to providing young people SRH education and services. However, in only a small number of countries have SRH initiatives and interventions moved from small scale and time limited projects to comprehensive, large scale and sustained programmes [12-14]. Colombia is one of the few countries in Latin America that has been able to implement and scale up differentiated SRH services, better known as Youth Friendly Health Services (YFHS) (in Spanish, Servicios de Salud Amigable para Adolescentes y Jóvenes) [15]. By 2013850 YFHS had been established across the country [16] .

The SRH of young Colombians has been a national public health concern and priority. In the past 20 years the proportion of pregnant adolescents aged 15-19 increased significantly (from $13 \%$ in 1990 to $20.5 \%$ in 2005) [17]. In the same age group there was an increase in the fertility rate (from 70 to 90 births per 1000 women between 1990 and 2005) [17] and in the unmet need and demand for family planning (from 10.7 to $14.4 \%$ and from 93.9 to $96.6 \%$ respectively); contraceptive use remained with an insignificant decrease from $83.2 \%$ in 2000 to $82.2 \%$ in 2010 [18]. Young women living in conditions of vulnerability - coming from rural areas and with low levels of education and economic income, are at higher risk of early pregnancies [19].

In 2007 the Colombian government initiated the implementation of YFHS in 10 departments of the country, in the context of a project supported by UNFPA [20, 21]. Since the inception of these services the MHSP had in mind a national implementation. Nevertheless, it did not have a clear planned strategy to do so but a national law that mandated its fulfilment.

This article presents and analyses the key factors and attributes that facilitated the scale up of YFHS in Colombia. The first part provides a description and a historical overview of the YFHS model implemented in Colombia. The second part presents an analysis of the scale up process using the ExpandNet framework of the World Health 
Organization (WHO-ExpandNet). The introduction of YFHS has not be completely smooth and some of the challenges and hinders met are also described and discussed. Finally, the article singles out some lessons learned and recommendations that can be useful in different contexts.

\section{Methodology \\ Data Sources}

We conducted a systematic and comprehensive literature search and review of SRH services for young people as well as national efforts to improve their quality of care targeting Colombia and neighbouring countries. We covered published and unpublished literature in Spanish and English.

The systematic search included various combinations of the following concepts: "Colombia", "Latin America", "adolescents","youth", "friendly health services","health services" and "reproductive health" in 8 databases (MEDLINE, PubMed, SCiELO, Academic Search Complete,
CINAHL plus, Cochrane library, HAPI online, LILACS REPIDISIC) and 6 websites of international organizations (WHOLIS, Pan American Health Organization, UNFPA, UNICEF, UNESCO, Andean Plan to Prevent Adolescent Pregnancy, and World Bank e-Library).

In the initial search we identified 430 articles, of which we selected 86 for initial review. Based on our inclusion and exclusion criteria, we identified one article and 11 reports on the YFHS Model in Colombia and six scientific articles and 14 reports on YFHS in LA for the final review (Table 1).

The inclusion criteria was that publications should present findings regarding the implementation and scale up of YFHS Model in Colombia and the status of YFHS and/or the SRH of young people in Colombia and LA in general. We excluded articles that focused on youth centres or programmes that did not implement the YFHS Model in Colombia.

Finally we collected and reviewed plans, reports, and presentations from the Ministry of Health and Social

Table 1 Publications on youth friendly health services in Colombia

\begin{tabular}{|c|c|}
\hline Title of the publication & Source or Author(s)/Year \\
\hline $\begin{array}{l}\text { "Este es tu centro, socio" Una experiencia exitosa de servicios de salud amigables } \\
\text { para jóvenes en Bogotá, Colombia. "This is your partner center" A successful } \\
\text { experience of adolescent friendly health services in Bogota, Colombia. }\end{array}$ & Toloza-Pérez; 2013 \\
\hline $\begin{array}{l}\text { Servicios amigables en salud para adolescentes y jóvenes. Un modelo para adecuar } \\
\text { las respuestas de os servicios de salud a las necesidades de adolescentes y jóvenes } \\
\text { de Colombia. Adolescent friendly health services. A model for adapting the responses } \\
\text { of health services to the needs of young people in Colombia. }\end{array}$ & Colombia: MSPS, UNFPA; 2007 \\
\hline $\begin{array}{l}\text { Lecciones aprendidas del proyecto del Fondo Mundial en Colombia. Proyecto Colombia. } \\
\text { Lessons learned from the Global Fund project in Colombia. Project Colombia. }\end{array}$ & Fernández D; 2007 \\
\hline $\begin{array}{l}\text { Servicios amigables para jóvenes: Construcción conjunta entre jóvenes y funcionarios. Health } \\
\text { care services for young people: A joint construction among youth and health personnel. }\end{array}$ & Valencia CP, et. Al; 2010 \\
\hline $\begin{array}{l}\text { La implementación de servicios de salud amigables para adolescentes y jóvenes en el } \\
\text { departamento de Huila. La experiencia de las ESE de Campoalegre, La Plata y Neiva. } \\
\text { Implementing adolescent friendly health services in the department of Huila. Experience } \\
\text { in Campoalegre, La Plata and Neiva. }\end{array}$ & Colombia: MSPS; 2010 \\
\hline $\begin{array}{l}\text { Intercambio de experiencias internacionales: Modelo SSAAJ. Exchange of international } \\
\text { experiences: Adolescent Friendly Health Service Model. }\end{array}$ & Plan Andino Prevención Embarazo Adolescente; 2011 \\
\hline $\begin{array}{l}\text { Avances en la implementación del modelo de servicios de salud amigables para } \\
\text { adolescentes y jóvenes. Análisis y evaluación 2010. Progress in implementing the } \\
\text { adolescent friendly health services model. Analysis and Evaluation. }\end{array}$ & Colombia: MSPS, UNFPA; 2011 \\
\hline $\begin{array}{l}\text { Evaluación sumativa de los Servicios de Salud Amigables para Adolescentes y Jóvenes en } \\
\text { Colombia. Summative Assessment of Adolescent Friendly Health Services in Colombia. }\end{array}$ & Colombia: MSPS, UNFPA; 2011 \\
\hline $\begin{array}{l}\text { Compromiso de los partidos y movimientos políticos. Por la promoción y la garantía de } \\
\text { los derechos humanos, sexuales y reproductivos. Commitment of political parties and } \\
\text { movements. For the promotion and guarantee of human, sexual and reproductive rights. }\end{array}$ & Colombia: UNFPA; 2011 \\
\hline $\begin{array}{l}\text { Indicadores de productividad de los SSAAJ y reporte de las Direcciones Territoriales } \\
\text { de Salud, Productivity of AFHS indicators and Regional Directorate of Health reporting. }\end{array}$ & Colombia: MSPS; 2012 \\
\hline $\begin{array}{l}\text { Servicios de salud amigables para adolescentes. Una revisión de su implementación y } \\
\text { principales características. Adolescent Friendly Health Services. A review of its implementation } \\
\text { and main characteristics. }\end{array}$ & Moreno-López D, Púa-Mora R; 2012 \\
\hline $\begin{array}{l}\text { Informe de Actividades 2012-2013. Sector Administrativo de Salud y Protección Social al } \\
\text { Honorable Congreso de la República. Activity Report 2012-2013. From the Health and } \\
\text { Social Protection Administrative Sector to the Congress of the Republic. }\end{array}$ & Colombia: MSPS; 2013 \\
\hline
\end{tabular}


Protection (MHSP) and the United Nations Population Fund (UNFPA) in Colombia. We also had meetings with representatives from the same agencies.

\section{Framework for Analysis}

The WHO-ExpandNet Framework is used to define and identify actors and actions that took place during the scale up process of the YFHS Model in Colombia.

The WHO-ExpandNet framework was developed by WHO to assist countries in scaling up health interventions with the aim of reaching more people, more rapidly and in more sustainable ways [22]. The WHO-ExpandNet framework establishes a practical scaling up guide, which comprises two sections that complement one another. The first section guides the systematic planning of the scale up strategy. Its elements are: the innovation to be scaled up, the user organization, the resource team, and the environment. The second section guides the strategic management of the scale up process, which is composed by the dissemination and advocacy, the organizational process, the costs/resource mobilization, and the monitoring and evaluation. Each of these elements must meet specific requirements for implementation. Tables 2 and 3 present the definition of these elements, as well as their characteristics of good practice.

The WHO-ExpandNet framework is also relevant to evaluating how scaling up of health interventions is done. In line with an approach we used in another paper [12], we decided to use this framework because it breaks down the model for scale up into pieces that can be examined closely and provides clear objective analysis criteria.

\section{History of introducing and scaling up the YFHS Model in Colombia}

Colombia has a long history of political commitment to making SRH services available for young people. The creation and implementation of the Program of Comprehensive Care for Adolescents in 1993 [23] and the prioritization of youth SRH strategies, in both the 2003 National Policy on Sexual and Reproductive Health and the 2007-2012 National Plan of Public Health, are among the most relevant milestones [24, 25].

The implementation of differentiated services by the MHSP for young people began in the 1990's as projects with limited geographical, temporal, and financial scopes. The effort of the Global Fund for AIDS Tuberculosis and Malaria to implement differentiated SRH services for young people in 48 municipalities of 25 departments between 2005 and 2008 provided important lessons learned to design the YFHS Model [26]. Firstly, it confirmed the perceived need of health facilities with availability of adequate SRH services and information for young people [26]. Secondly, it showed that the absence of standardized protocols to assist young people, flexible schedules of operation, and processes for monitoring services can hinder the quality and sustainability of services provided [27]. The HIV/AIDS programming stimulated scale up since it provided a broader approach to HIV including comprehensive sexuality education and availability of youth friendly services.

In 2007, the MHSP signed an agreement of collaboration with UNFPA to design and implement differentiated health services for young people, known as the YFHS Model. The design of the Model followed a process that

Table 2 World Health Organization-expandNet framework-planning the scaling up strategy

\begin{tabular}{|c|c|c|}
\hline Elements & Definition & Characteristics of good practice \\
\hline Innovation & $\begin{array}{l}\text { The interventions and/or practices } \\
\text { to be scaled up }\end{array}$ & $\begin{array}{l}\text { Relevant, Credible, Clear, Compatible with } \\
\text { values and norms, Easy to install }\end{array}$ \\
\hline User Organization & $\begin{array}{l}\text { The institution that adopts and } \\
\text { implements the innovation at scale }\end{array}$ & Credible, Commitment, Capacity \\
\hline Resource Team & $\begin{array}{l}\text { Individuals and organizations that } \\
\text { have been involved in the development } \\
\text { and testing of the innovation and/or seek } \\
\text { to promote its wider use }\end{array}$ & Leadership, Credibility, Commitment, Capacity \\
\hline Environment & $\begin{array}{l}\text { The conditions and institutions, external } \\
\text { to the user organization, that substantially } \\
\text { affect the prospects for scaling up }\end{array}$ & $\begin{array}{l}\text { Understanding the challenges and opportunities } \\
\text { in the environment and taking them into account }\end{array}$ \\
\hline Vertical scaling up strategy & $\begin{array}{l}\text { The policy, political, legal, regulatory, } \\
\text { budgetary or other health systems } \\
\text { changes needed to institutionalize } \\
\text { the innovation }\end{array}$ & $\begin{array}{l}\text { It 'legitimizes' the innovation, integrates it in } \\
\text { national and sub-national work plans and budgets } \\
\text { and thus increases the likelihood of it being applied } \\
\text { nationwide over a sustained period }\end{array}$ \\
\hline Horizontal scaling up strategy & $\begin{array}{l}\text { The replication of the innovation in different } \\
\text { geographic sites or its extension to larger or } \\
\text { different population groups. }\end{array}$ & Wider application and reach out of the innovation \\
\hline
\end{tabular}


Table 3 World Health Organization-expandnet framework-strategic management of the scale up effort

\begin{tabular}{ll}
\hline Elements & Characteristics \\
\hline Communication and advocacy & $\begin{array}{l}\text { It is the availability of appropriate approaches and relationships for } \\
\text { advocacy on, introduction of, and information about the innovation } \\
\text { to reach key audiences } \\
\text { It is the path followed by the scale up process. It stresses the importance } \\
\text { of charting out the management process, its pace and scope, whether it } \\
\text { is to be centralized or decentralized, whether it is to be adaptive or fixed } \\
\text { and who would drive the process } \\
\text { It stresses the importance of integrating scaling up efforts into national } \\
\text { and sub-national work plans and budgets, and of tapping into existing } \\
\text { funding mechanisms } \\
\text { It stresses the critical importance of monitoring and evaluation using } \\
\text { methods such as such as routinely gathered statistics, special surveys } \\
\text { and formative and intervention-effectiveness research }\end{array}$ \\
\hline
\end{tabular}

Source. WHO 2010. Nine steps for developing a scaling-up strategy, Geneva, Switzerland, World Health Organization

included a review of international recommendations for making services youth friendly, meetings within the MHSP, the General Social Security System (GSSS), and UNFPA to assess the feasibility of such recommendations, and consultations with young people to identify how well these services were received and met youth needs. At the end of this process the MHSP presented the goals of the YFHS Model as to reduce barriers to accessing SRH services, to promote active participation of young people in the design of SRH programs, and to strengthen the institutional capacity of the GSSS [20].

The MHSP, the GSSS and UNFPA, based on the characteristics of the Colombian health system and its capacity to provide services, recommended that the Model followed two principles. Firstly, health facilities adopting the Model should have five components: a) easy and

Table 4 Components and characteristics of the AFHS Model in Colombia

\begin{tabular}{|c|c|}
\hline Component & Characteristics \\
\hline \multirow[t]{6}{*}{ Access and opportunity in service delivery } & Infrastructure and geographical accessibility \\
\hline & Physical setting \\
\hline & Identification of the service \\
\hline & Differentiated hours of operation and appointment scheduling \\
\hline & $\begin{array}{l}\text { Enabled services based on national policies in sexual and reproductive } \\
\text { health }\end{array}$ \\
\hline & Acknowledgment of services by adolescents and young people \\
\hline \multirow[t]{5}{*}{ Health professionals and staff } & Trained in adolescent friendly and differentiated services \\
\hline & Confidential \\
\hline & Respectful of cultural and gender diversity, economic situation, etc. \\
\hline & $\begin{array}{l}\text { Capable to identify prejudices, stereotypes and emotions that make it } \\
\text { difficult to empathize or provide services }\end{array}$ \\
\hline & $\begin{array}{l}\text { Not feeling obligated to abandon personal beliefs or values; } \\
\text { but willing to understand views of adolescents }\end{array}$ \\
\hline \multirow[t]{3}{*}{ Administrative and management procedures } & Suitable to provide comprehensive services \\
\hline & Adoption of national standards and policies (Decree 1011 of 2006) \\
\hline & $\begin{array}{l}\text { Readjusted route that adolescents and young people follow from the } \\
\text { moment they enter until they leave the facility }\end{array}$ \\
\hline \multirow[t]{2}{*}{ Availability of a wide range of services } & Defined according to the set up of care and the needs of young people \\
\hline & Continued with other levels of care/reference and counter-reference levels \\
\hline \multirow{3}{*}{$\begin{array}{l}\text { Youth, social, and community participation as well } \\
\text { as inter-sectorial coordination }\end{array}$} & Services empowered by young people \\
\hline & Inter-sectorial actions \\
\hline & Working agreements with social organizations \\
\hline
\end{tabular}


timely accessibility, b) personnel trained in YFHS, c) administrative and management processes in place that respond to quality standards of YFHS provision, d) availability of a wide range of health services, and e) youth, community, and social participation as well as intersectoral coordination (See Table 4). Secondly, the health facility would adopt one of three types of set up: a) differentiated service, b) friendly unit or c) friendly centre (See Table 5). This design was subject to review and adjustment depending on conditions and realities of the different regions in the country and the providers' execution ability to implement the Model [20].

The scale up of the YFHS Model followed a systematic path and assigned specific responsibilities to key players at different levels of the health system; which consists of the MHSP and the GSSS. The MHSP as the national entity in charge of developing public health policies, mandated the implementation of the Model, worked with the Regional Directorate of Health (RDH) and Local Directorate of Health (LDH) to press for the inclusion of the Model in their operational plans, allocation of financial and human resources, and incorporation of information systems to ensure the implementation and monitoring of the Model, and providing training on YFHS to the GSSS' personnel. The GSSS as the set of programmes and institutions that directly provide health services to the population through private and public Providers of Healthcare Services (PHS), made available one of the three modalities of care of YFHS [15, 20].

The scale up of the YFHS Model followed vertical and horizontal strategies. The vertical strategy involved institutionalizing the Model within the MHSP and GSSS. Table 6 lists in chronological order the enactment of laws and resolutions that supported this scale up.

The horizontal strategy consisted of countrywide scaling up the Model in departments, districts, and municipalities. In 2007 the YFHS Model was approved to be implemented nationally; but without a clear plan in terms of coverage. In 2008 it was officially launched in ten departments. The scale up process took place in phases with an annual increase of health facilities adopting the Model. By 2009, 290 health facilities had implemented the Model. In the following four years a total of 817 new ones were added (371, 213, 49, and 184 in 2010, 2011, 2012 and 2013 respectively). The 2010 qualitative evaluation reported that the total of health facilities with the Model, $84 \%$ of them were differentiated services, $14 \%$ friendly units, and $<1 \%$ friendly centers [28]. By 2013, 30 out of 32 departments and 536 out of 1198 municipalities had YFHS (52\% in municipalities and $94 \%$ in the public sector) [29]. Although these numbers mean there is still a way to go to reach national coverage this level of scale is among the most successful in Latin America.

\section{Results: Applying the ExpandNet framework to examine the scale up of the YFHS Model}

This section is divided into two main segments: The systematic planning and the strategic management of the scale up process. In each segment, we assessed the key elements of the WHO-ExpandNet framework and whether or not they fulfil the criteria of good practice. (See Tables 2, 3).

\section{Planning the scaling up strategy Innovation}

The innovation or the intervention to be scaled up was the YFHS Model. According to the WHO-ExpandNet framework, the attributes of good practices of innovations are clarity, credibility, relevancy, compatibility, and easy installation.

In Colombia the attributes of the YFHS Model were clear. The MHSP in collaboration with UNFPA developed a manual titled 'Friendly Health Services for Young People' to create a shared understanding of the YFHS Model's characteristics. The manual defined youth friendly services as "health facilities that provided care to young people aged 10-29, offered a range of accessible and timely services and quality care, and were adapted to young people's reality [20]". To be considered youth friendly these facilities guaranteed geographic accessibility, privacy and confidentiality, adequate hours of operation for young people, health personnel trained in YFHS, availability of a wide range of services, and opportunities for young people and members of the community to participate in the continuous improvement of these facilities.

Table $\mathbf{5}$ Set ups of the AFHS model in Colombia

\begin{tabular}{ll}
\hline Set up & Characteristics \\
\hline Differentiated service & $\begin{array}{l}\text { Delivery of services by a trained professional in AFHS in any health facility. } \\
\text { Services may be available within the normal operation hours of the facility. }\end{array}$ \\
Friendly Unit & $\begin{array}{l}\text { Physical space, in a facility, destined for young people, with differentiated } \\
\text { hours of operation and run by trained professional in AFHS }\end{array}$ \\
Friendly Facility & $\begin{array}{l}\text { Exclusive facility for adolescents and young people with trained professional } \\
\text { in AFHS and with areas of interaction for young people }\end{array}$
\end{tabular}

Source: Ministerio de Salud y Protección Social Colombia, UNFPA. (2007). Servicios amigables en salud para adolescentes y jóvenes. Un modelo para adecuar las respuestas de los servicios de salud a las necesidades de adolescentes y jóvenes de Colombia. Bogotá D.C., Colombia 
Table 6 Political process that strengthened the implementation of the AFHS Model in Colombia

\begin{tabular}{ll}
\hline 1968 & Creation of the National Institute for Youth and Sports \\
\hline $1990-1994$ & Creation of the Presidential Program for Youth, Woman and Family \\
1993 & Launch of the Manual of Technical and Administrative Regulations for Comprehensive Care of Youth \\
1994-1998 Creation of the Vice Ministry of Youth, under the Ministry of Education. & In 2000 becomes the Presidential Program Young Colombia \\
& Enactment of Act 375 or Youth Law \\
1997 & Enactment of the National Policy on Sexual and Reproductive Health (SRH) \\
2003 & Circular 18. Health insurance companies and local secretaries of health guarantee care for young people \\
2004 & Act 1098. Code for Children and Adolescents. Guarantees free access to SRH services for young people, development \\
2006 & of programs to prevent unwanted pregnancies, and priority attention to adolescent mothers \\
2006 & Sentence C355 and Decree 4444. Decriminalize abortion in case of: a) Pregnancy endangers life/health of women, \\
& b) Severe fetal malformation, C) Pregnancy result of sexual intercourse or sexual act without consent \\
2007 & Decree 3039. Adopts the National Plan of Public Health and joins the Plan Andino to Prevent Adolescent Pregnancy \\
2007 & Act 1122. Recommends the implementation of the Adolescent Friendly Health Services (AFHS) Model \\
2008 & Beginning of the national implementation of the model AFHS \\
2008 & Resolution 425. Collective Intervention Plan. Contemplates mandatory implementation of the AFHS model \\
2010 & Decree 2968. Creates the National Inter-sectorial Commission to promote and guarantee sexual and reproductive rights
\end{tabular}

Source: Ministerio de Salud y Protección Social Colombia, UNFPA. (2007). Servicios amigables en salud para adolescentes y jóvenes. Un modelo para adecuar las respuestas de los servicios de salud a las necesidades de adolescentes y jóvenes de Colombia. Bogotá D.C., Colombia

Mejía-Gómez ML, Montoya-Chica P, Blanco-Rojas AJ, et al. (2010). Barreras para el acceso de adolescentes y jóvenes a servicios de salud. Propuesta para su identificación y superación. Documento regional - 2010 Bogotá D.C., Colombia

Ministerio de Salud y Protección Social Colombia. (2010). La implementación de servicios de salud amigables para adolescentes y jóvenes en el departamento de Huila. La experiencia de las ESE de Campoalegre, La Plata y Neiva. Bogotá D.C

The manual provided health personnel and authorities from the GSSS with national quality standards for the design, implementation, monitoring, and evaluation of these services. This standardization contributed to ensuring that all players in the health system understood what the concept of YFHS Model meant and how each one would need to participate to make a health facility youth friendly.

The approach of the innovation to improve the SRH of young people was credible and supported by international agreements. The model promotes a rights based approach for access to SRH services, responding to the resolutions of the 1997 Convention to Eliminate Discrimination Against Women. The Model also offers resources that help young people understand their sexuality, prevent unwanted pregnancies and sexually transmitted diseases (STIs), as recommended by the calls made in Cairo and Beijing.[30, 31].

The design of the innovation in Colombia specifically included ongoing participation of health representatives of the government, departments and municipalities, international agencies, civil society including young people as demonstrated by five task-force meetings between 2007 and 2008 [20] and a qualitative evaluation of the Model in 2010. This process helped shaped a Model that responded to local context of the health system and the needs of young people, increasing the likelihood of demonstrating health benefits among them [32].
The innovation was relevant to addressing the elevated rates of adolescent pregnancy by making available friendly services and information on SRH.

The YFHS Model did not meet all the characteristics of good practice recommended by the WHO-ExpandNet. The installation of the Model was neither smooth nor easy to transfer. The operation of the GSSS between private and public PHS was uneven, particularly regarding financial and human resources [33]. A documentation of the model in three regions of the department of Huila highlighted that the reasons that jeopardized the scale up of the Model were lack of funding to recruit and retain trained personnel, lack of physical spaces to implement YFHS, and disinterest in the Model among some administrative authorities [34]. The National Summative Evaluation of the Model identified that even after adopting the Model, some health facilities did not implement guidelines for serving youth [28].

\section{User organization}

The ExpandNet framework defines the user organization as the institution that adopts and implements the innovation on a large scale [22]. In Colombia this organization was found at three levels: a) National, b) Departmental, and c) Municipal. These three levels relied on their leadership - design and implement new policies, develop private and public PHS work plans and budgets; 
and commitment to scale up the Model, but the high turnover of human resources and weak political interest among some health authorities limited their implementation capacity.

a) At the national level the MHSP led the implementation of the model. The MHSP had the capacity to implement it, train health personnel, and track and monitor its implementation at the departmental and municipal levels. The MHSP's leadership and commitment strengthened its credibility; it also influenced the involvement of other institutions and sectors during the scale up process.

b) At the departmental level, the RDH was responsible for implementing, providing technical assistance to municipalities and, when necessary, monitoring actions recommended in the Model as well as collecting and analysing information to be forwarded to the national level. Not all RDHs were committed to the innovation; thus the efforts and political will to scale up the Model differed. By 2013 the departments of Atlántico, Huila, Tolima, and Valle de Cauca achieved coverage of YFHS implementation per municipality higher than $90 \%$. In other departments coverage varied, with some as low as $5 \%$ [29].

c) At the municipal level, private and public PHS implemented the Model. Managers of social services organized and ensured provision of necessary services. Where there was commitment to the Model, there was also a smooth internal adoption of policies and the availability of health services. However, variable governance and financial resources, high turnover of trained personnel, and challenges in contracting new staff, affected the Model's scale up and sustainability [15].

\section{Resource team}

The MHSP and UNFPA Colombia provided the resource team. These organizations had the leadership, credibility, commitment and ability to facilitate the implementation and national scale up of the Model.

For nearly 40 years UNFPA has worked in Colombia to build capacity for the improvement of the SRH of its population and contribute to the overall development of the country. When UNFPA signed the agreement of collaboration with the MHSP it also agreed to provide technical expertise and financial resources to launch and scale up the Model. UNFPA funded the pilot phase in 10 departments, designed and produced the manual "Friendly Health Services for Young People" and other didactic materials, and provided systems for monitoring and evaluation [20]. Similarly, UNFPA provided MHSP opportunities to establish international collaboration and to exchange experiences on scaling up YFHS with other countries. To this date UNFPA continues to provide financial support to the implementation of the Model; although the percentage of funding decreased over time (From 44 in 2007 to $27 \%$ in 2010 and less than $5 \%$ in 2013) [16].

The authority and leadership of the MHSP was essential for the acceptance and adoption of the Model among the different actors of the GSSS.

\section{Environment}

The main environmental factors, i.e., the conditions influencing the scale up process of the Model, were national policies on SRH for young people, the structure of the MHSP and GSSS, and socio-cultural perceptions about SRH services for young people as well as the ongoing effort to identify champions for the YFHS Model among government officials outside of the MHSP.

a) National policies. The political commitment to improve the health of young Colombians was expressed through the formulation and implementation of various national laws and regulations. The enactment of the National Policy on SRH, the Code on Children and Adolescents, and the National Public Health Plan 2007-2010 were some of the most influential initiatives during the scale up process. The MHSP and UNFPA involved authorities from the Ministry of Education, Ministry of Information and Communication, National Learning Service, Colombian Institute for the Wellbeing of Families, as well as the Social Action and Young Colombia programmes, in order to promote and guarantee the implementation of the model within each respective agency or programme. This led to the establishment of the Inter-Sectoral National Commission to promote and guarantee SRH rights in Colombia [21]. See Table 6.

b) Structure of the GSSS. The decentralized characteristics of the GSSS, the regular turnover of health authorities, and the uneven availability of and access to financial and human resources between public and private health facilities impeded the implementation and scaling up of the Model, particularly in private health facilities since they have more flexibility in choosing what services in general they offer as opposed to public ones Involvement of new RDH, $\mathrm{LDH}$, and PHS authorities had to be done on an ongoing basis to ensure the continuity of the implementation of the Model.

c) Socio-cultural perceptions. The demand for SRH services and information was not a common practice among young people, and was not approved 
by parents and other community members. Young people were uncomfortable seeking SRH services because of how they could be seen, judged, and treated. Among adults, the beliefs and perceptions about the SRH of young people, including early initiation of sexual intercourse, contraception and pregnancy in this group were seen as incompatible to their religious beliefs and social practices [28]. Thus, the inclusion of young people, parents and community members as stakeholders was critical for the adoption and scale up of the model.

The first link with stakeholders came from the formation of "social oversight committees of young people", known as "Veedurías" in Spanish. "Veedurías" were formed by young people, parents, and other community members. They disseminated information about the characteristics of YFHS to the general public. They also participated in the design and monitoring of interventions in health facilities adopting the model. Until 2012, 38 active "veedurías" supported the scale up the model in 11 departments of the country [35].

The second link with stakeholders was with health personnel who recognized young people as individuals with rights to information about SRH and access to quality SRH services. Their high turnover demanded continuous sensitization and training on youth friendly services. The MHSP provided this training and coordinated with ten universities across the country to establish a Certificate of Reproductive Rights and Sexual Health of Adolescents. Between 2012 and 2013, 302 health personnel graduated from the programme and were qualified to work with young people [35].

\section{Scaling up strategy}

According to the WHO-ExpandNet framework the scaling up strategy can be: Vertical, horizontal, diversified, and spontaneous. Colombia adopted a combination of vertical and horizontal strategies.

The vertical strategy consisted of the institutionalization of the Model within national health public policies and its inclusion in the Mandatory Health Plan of the GSSS. To ensure that the scale up of the YHFS maintained its quality standards, the MHSP -through Act. 1122 and Resolution 425, mandated its implementation. At the subnational levels, public and private PHS adopted the Model based on its context and capabilities. This horizontal strategy consisted on providing on-going support and training on YFHS to different members of the GSSS.

\section{Strategic management of the scaling up process Dissemination and advocacy}

The basis of the advocacy effort was MHSP's commitment to making YFHS available nationally. The enactment of
1122 Act recognized the Model as an element of a multifaceted strategy to improve the SRH of young people. The Resolution 425 or Collective Intervention Plan strengthened the adoption of the model by different actors of the GSSS. Likewise, the MHSP contributed to international agreements and inter-institutional cooperation that supported this process. In 2011 the President of Colombia led the initiative to sign the Commitment of the political parties and movements to promote and guarantee sexual and reproductive health rights. Through this agreement government authorities were accountable for the execution and continuity of interventions that seek to reduce the rate of adolescent pregnancy, including the Model [21].

Advocacy among community members was also essential to achieve acceptance and adoption of the model. This was obtained, among other strategies, by establishing the "veedurías."

\section{Organizational process}

The scale up process of the model was in phases, consistent, and continuous. Each year the number of regions executing the model, PHS adopting the Model, conducting training workshops and training personnel increased progressively.

The MHSP was consistent in running the processes of dissemination, training, and technical assistance during the scale up of the Model. It was also flexible to adapt it according to local characteristics and needs as well as the infrastructure and availability of public and private health institutions. For instance, in 2013 from a total of 817 health facilities implementing the Model the majority adopted the differentiated service modality, and to a lesser extent, the friendly unit and friendly centre modalities [29].

The scale up of the Model was decentralized to departments with variations in speed, scope of the population, and places to be reached. For example, a review of the implementation of the model in Huilla details how this department managed to expand the Model in 20 municipalities within 2 years [34]. By 2013, the scale up of the model reached 30 of the 32 departments. Similarly, between 2009 and 2013, Atlántico and Valle del Cauca reached $100 \%$ coverage of YFHS per municipality. On the contrary, other departments were slower, abandoned the initiative, or did not implement it at all due to a weak political commitment among town counsellors, health officials or hospitals' managers thus less financial and human resources $[29,36]$.

The demographic and geographic limitation of scaling up the Model was directly related to the scope of the PHS. According to the GSSS, some private PHS serve the population mainly on a contributory scheme, whereas public PHS usually assist the uninsured or those who cannot afford medical care. Coverage was lower among private 
PHS because not all of them adopted the Model, and in the ones who did it young people had to use their insurance or pay to get the services [25].

\section{Costs/resource mobilization}

The MHSP, UNFPA, UNICEF, and the Andean Plan to Prevent Adolescent Pregnancy were the main sources of funding for the scale up effort. Allocated resources were adequate and sufficient to carry out the pilot phase, train health personnel, establish new YFHS as well as processes for monitoring and evaluation, develop and distribute educational materials, and organize interagency events to discuss the progress of the model.

The scale up of the Model, however, did not have reliable and predictable long-term funding at the municipal level. Reviews of the Model indicate that delays in allocating financial resources from the national level to PHS limited the availability of supplies and medicines for patients. PHS that did not incorporate the model in their institutional Development Plan were not able to guarantee continuous funding of trained personnel and commitment to sustain the model $[15,33,34]$.

\section{Monitoring and evaluation}

The MHSP designed robust monitoring and evaluation processes with clear data collection tools. The MHSP also assigned specific institutions and personnel to collect, analyse, and submit that data [20]. Table 7 provides the list of instruments used to measure the quality and coverage of the YFHS Model.

This process was in place since the beginning of the model. In 2009 and 2010, the MHSP carried out surveys to track implementation of the model (Annex A4 and Annex A11) [37]. The results enabled the MHSP to identify the determinants of success and failure of the scale up process; as well as criteria to point to which components of the model required strengthening or further attention to improve the quality of services provided. Table 8 and Figs. 1 and 2 summarize the findings of the evaluation.

Table 7 Measurement tools to assess the quality and coverage of the AFHS Model

\footnotetext{
$\rightarrow$ Vital statistics DANE (Births and deaths)

$\rightarrow$ Individual registry of service provision (RIPS in Spanish)

$\cdot \rightarrow$ Single registry of affiliates to the social protection system (RUAF in Spanish)

$\cdot \rightarrow$ Management system indicators

$\rightarrow$ Annex A4 - Tool to analyse health services based on the components of the AFHS model

$\rightarrow$ Annex A11 - Self-administered survey for adolescents and young people
}

Source: Ministerio de Salud y Protección Social Colombia, UNFPA. (2007). Servicios amigables en salud para adolescentes y jóvenes. Un modelo para adecuar las respuestas de los servicios de salud a las necesidades de adolescentes y jóvenes de Colombia. Bogotá D.C., Colombia
Table 8 Summary of the 2010 summative evaluation of the AFHS Model

\begin{tabular}{ll}
\hline Total of AFHS & 733 \\
\hline $\begin{array}{l}\text { Number of facilities reporting implementation } \\
\text { of the AFHS Model }\end{array}$ & 372 \\
$\begin{array}{l}\text { Total of health professionals implementing } \\
\text { the AFHS Model }\end{array}$ & 43.605 \\
Total of youth visits & 280.564 \\
Total of family planning visits & 151.168 \\
Total of youth using contraception & 403.804 \\
Total of youth seeking SRH advisory services & 140.954 \\
Total of youth deliveries & 10.683
\end{tabular}

Source: Colombia MSPS: Consolidado de Indicadores 2013. Servicios de Salud Amigable para Adolescentes y Jóvenes. 2014

In practice, the information management system was inadequate at different levels of the user organization, especially on making data available on time [15, 37]. Getting immediate, reliable and updated data about the scale up of the model remains a challenge due to the continuous turnover of data analysts.

\section{Building on the lessons of the effort to scale up YFHS and taking remedial action}

The implementation cycle of the YFHS Model was characterized by ongoing identification of performance components that needed improvement and taking of remedial actions. In 2009, the MHSP organized the first national meeting on lessons learned from the implementation of the Model with the participation of representatives of PHS implementing the Model and young people.

The meeting concluded with a list of suggestions to improve the scope of the Model as the scale up occurred, which became the basis for the MHSP's further strategic remedial action. Overall it took almost three years to document the accomplishment of those actions. The MHSP took seriously the need to strengthen youth participation in the implementation of the Model. Since 2012, the MHSP implemented the idea of "veedurías" (social oversight committees) for young people within the Model [38] and identified and strengthened youth networks and organizations as well as created regional and national youth councils to prevent adolescent pregnancy [39]. In 2013 the MHSP established an agreement that funded youth strategies that would enhance public participation to identify local actions to prevent adolescent pregnancy, promote SRH rights, and prevent STIs including HIV [40].

Another remedial action was the development of training strategies for healthcare providers on youth SRH and rights. The MHSP partnered with UNFPA and national universities to create a graduate curricula on adolescent $\mathrm{SRH}$, which as mentioned in previous paragraphs, reached over 300 health providers in four major cities [41]. 


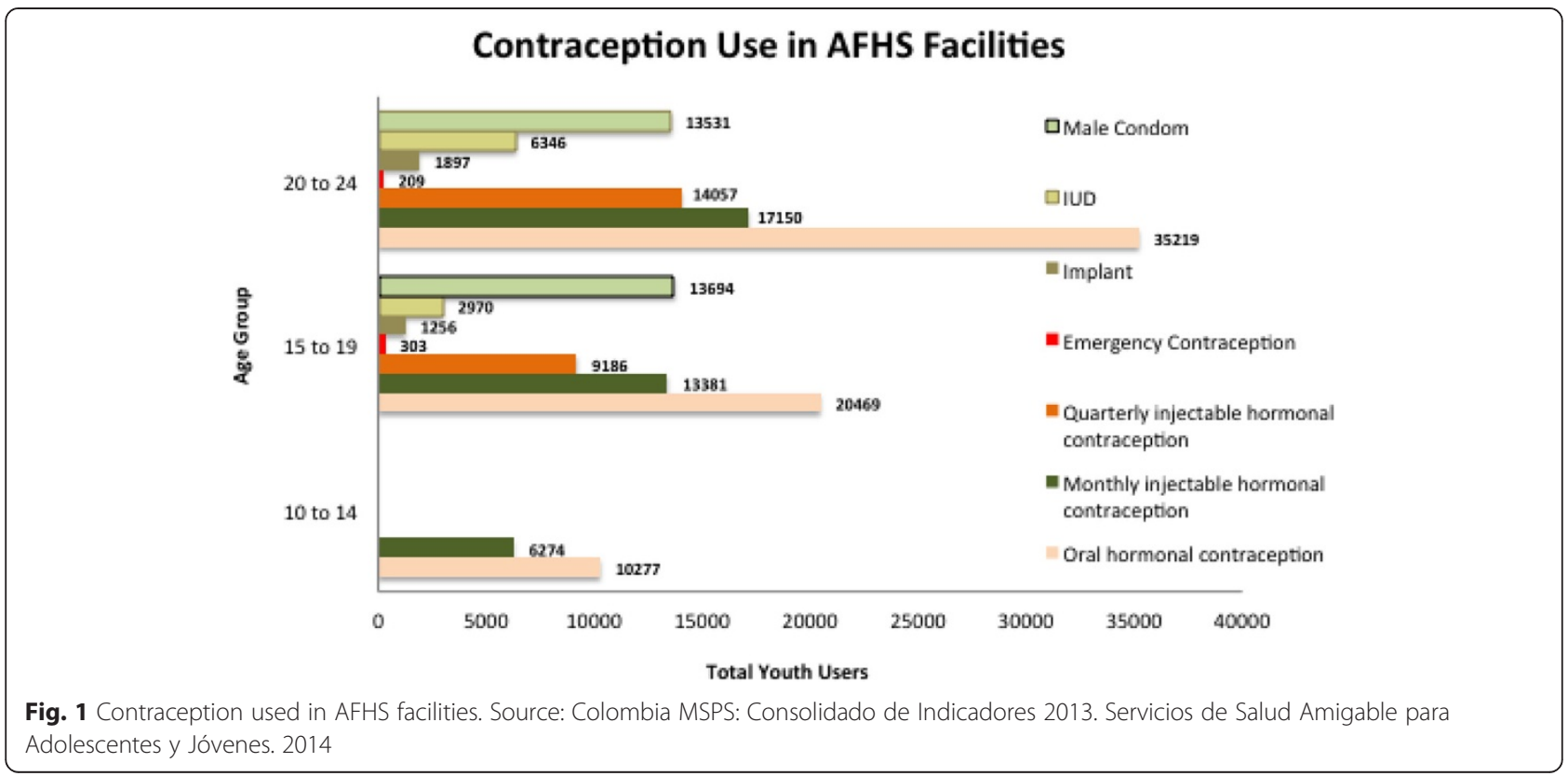

The MHSP has also worked on adapting the Model for young people coming from indigenous groups. By early 2014 it had been adapted by the indigenous communities of Nariño and la Guajira [42].

Finally, the MHSP has looked for strategies to strengthen the procurement processes of YFHS and standardize the tools used for data collection. To do so, it developed a standard matrix on Microsoft Excel that included YFHS indicators, definitions, and guidelines to facilitate the introduction of YFHS data. As this matrix was distributed nationally, the MHSP trained health providers on its use. Despite these efforts, the use of this matrix and the availability of national YFHS coverage data remains a challenge.

\section{Discussion}

The efforts to establish and scale-up SRH services for young people in Colombia have led to significant achievements but have also faced a range of challenges. Despite this, Colombia is one of few LA countries that has achieved national implementation of YFHS although with an uneven coverage across the departments. The lessons learned from this effort could help strengthen the work in Colombia, and as well as in other countries are doing to provide comprehensive SRH services to young people in a sustainable manner.

What are the elements that made possible the implementation and scale up of the YFHS Model in Colombia?

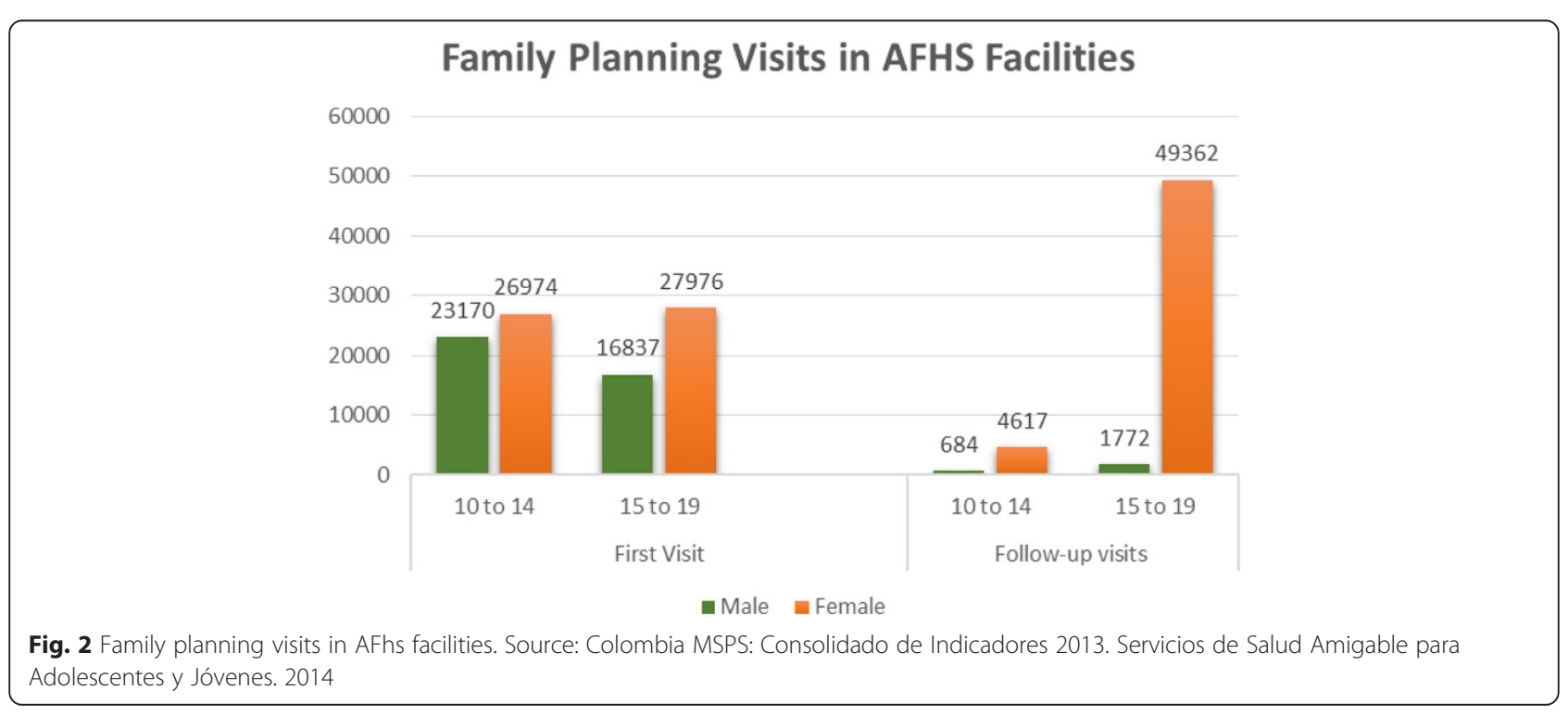


The WHO-ExpandNet framework allowed us to identify five elements that contributed to this process.

First, the Model was built on momentum in the country to support initiatives that improve the SRH of prevent pregnancies among young people. National health policies established clear guidelines for the implementation of the Model within the GSSS. Clear policies and implementation guidelines on the YFHS Model was an important attribute in the scale up process.

Second, political stakeholders and advocates strongly endorsed the YFHS Model. The leadership of the MHSP and UNFPA helped ensure the recognition of the Model with relevant government ministries, and within the health system. At the same time the MHSP built significant alliances with international institutions. This solid inter-sectoral and interagency collaboration was important in providing the technical and financial resources necessary as the scale up process occurred.

Third, the work of the MHSP and UNFPA as the resource team, and the former as a user organization as well, favoured the scale up process by providing the necessary technical and financial resources.

Fourth, the continuous involvement of different members of the community and young people themselves in the improvement of health facilities led to ownership and sustainability of these services, which helped address negative socio-cultural perceptions about the provision of SRH information and services to young people. The strong involvement and community empowerment was key to reach large-scale implementation.

Fifth, despite its limitation, the presence of a monitoring and evaluation component allowed the identification of elements in the model that required strengthening or further attention. Effective use of information contributed to the continuous improvement of the model as the scale up occurred.

The scaling up of the model did not follow a smooth process. The elements that limited or slowed down this effort were: First, the insufficient number of health personnel trained in youth health and their high turnover. Second, a decentralized SGSS that caused variability in institutional management and distribution of financial resources at the departmental and municipal levels. Given that funding was dependant on the inclusion of the Model in the municipal operating plan, decentralization did not guarantee continuation of health personnel implementing the Model. Finally, the negative perceptions among community members to provide SRH information and services to adolescents hindered implementation.

So far no attempt has been made to measure the impact of the implementation of the Model in terms of uptake of services or health outcomes. The development of a monitoring and evaluation framework is under way and this will hopefully provide data about the degree to which the
Model succeeds in helping young people protect their SRH. Although more than 800 clinics have become youth friendly, which in itself is a major achievement, there is still a long way to go to reach the majority of adolescents in the country. Both vertical and horizontal scale-up must be pursued to reach a larger number of young people.

\section{Conclusion}

The experience of scaling up youth friendly health services in Colombia demonstrates the need to establish clear policies and implementation guidelines at all levels of the health system. Inter-sectoral and interagency collaboration to establish the standard of required quality of health care and the identification of champions that lead and strengthen the implementation of the YFHS Model facilitate its implementation and monitoring. It also illustrates the importance of emphasizing the quality of services and continuous training of health personnel in the SRH of young people, as well as the inclusion of young people in the design, execution, and monitoring of services.

The main challenges in scaling up the YFHS Model in Colombia were the decentralized management system and the lack of commitment among some of regional and local authorities that limited the continuity, sustainability and increase in coverage of the model. It highlights the need to invest time and resources right from the beginning to get the buy-in and support of the lower levels, and ensuring their participation.

\section{Endnotes}

${ }^{1}$ The World Health Organization (WHO) defines young people as those between the ages 10-24. It includes Adolescents (10-19) and youth (15-24).

\section{Competing interests}

The authors declare that they have no competing interests.

\section{Author contributions}

Venkatraman Chandra-Mouli conceived the idea for this documentation and was involved in its design and review. Silvia Huaynoca led the systematic review and the write up of the manuscript. Joar Svanemyr contributed in the write up, review and edit of the manuscript. Diva Jeaneth Moreno Lopez contributed in the review of the manuscript. All authors read and approved the final manuscript.

\section{Acknowledgements}

We want to thank the Colombian authorities from the Ministry of Health and Social Protection as well as UNFPA for agreeing working on us and providing all information needed.

This study is supported by the Department of Reproductive Health and Research from the World Health Organization.

\section{Author details}

'Independent Consultant, 125 Maiden Lane, 9th Floor, New York, NY 10038, USA. ${ }^{2}$ Department for Reproductive Health and Research, WHO, 20 Avenue Appia, 1211 Geneva, Switzerland. 32Dirección de Promoción y Prevención, Ministerio de Salud y Protección Social Colombia, 37-76 1st Floor, Carrera 13, PO Box 110311, Bogotá, Colombia.

Received: 26 September 2014 Accepted: 9 September 2015

Published online: 18 September 2015 


\section{References}

1. United Nations. World Population Prospects: 2008 Revision. Highlights working paper No ESA/P/WF 210, Department of Economics and Social Affairs. Population Division 2009. 2011

2. UNICEF. Adolescence. An Age of Opportunity, United Nations International Children's Emergency Fund. New York: UNICEF; 2011.

3. PAHO. Plan y Estrategia Regional de Salud Adolescente. Washington: Pan American Health Organization; 2010.

4. Gore FM, Bloem PJ, Patton GC, Ferguson J, Joseph V, Coffey C, et al. Global burden of disease in young people aged 10-24 years: a systematic analysis. Lancet. 2011;377:2093-102.

5. Halcon L, Blum RW, Beuhring T, Pate E, Campbell-Forrester S, Venema A Adolescent health in the Caribbean: a regional portrait. Am J Public Health. 2003;93:1851-7.

6. Viner RM, Coffey C, Mathers C, Bloem P, Costello A, Santelli J, et al. 50-year mortality trends in children and young people: a study of 50 low-income, middle-income, and high-income countries. Lancet. 2011;377:1162-74.

7. Patton GC, Coffey C, Sawyer SM, Viner RM, Haller DM, Bose K, et al. Global patterns of mortality in young people: a systematic analysis of population health data. Lancet. 2009:374:881-92.

8. Mejía-Gómez ML, Montoya-Chica P, Blanco-Rojas AJ, Mesa M, Moreno-López DJ, Pacheco-Sánchez Cl. Barreras para el acceso de adolescentes y jóvenes a servicios de salud, Propuesta para su identificación y superación. Bogotá D.C: Documento regional; 2010.

9. de Chile G. Estudio barreras de acceso a los servicios de salud para la prevención del embarazo adolescente en Chile. Estudio realizado por la organización CulturaSalud para el Programa Nacional de Salud Integral de Adolescentes y Jóvenes del Ministerio de Salud. Chile: Gobierno de Chile; 2010.

10. Salinas-Mulder S, Castro-Mantilla MD. Diagnóstico sobre el estado actual de la salud y los derechos sexuales y reproductivos en Bolivia. La Paz: Plan Andino para la Prevención del Embarazo Adolescente; 2011.

11. Palazzo Ldos S, Beria JU, Tomasi E. Adolescent clients of primary health care services. How do they live? Why do they seek help, and how do they express themselves? Cad Saude Publica. 2003;19(6):1655-65.

12. Huaynoca S, Chandra-Mouli V, Yaqub N, Denno D. Scaling up sexuality education in Nigeria. From national policy to nationwide application. Sex Edu: Sexuality, Soc Learning. 2013;14(2):191-209.

13. Chandra-Mouli V, Mapella E, John T, Gibbs S, Hanna C, Kampatibe N, et al. Standardizing and scaling up quality adolescent friendly health services in Tanzania. BMC Public Health. 2013;13:579.

14. Chandra-Mouli V, Baltag V, Ogbaselassie L. Strategies to sustain and scale up youth friendly health services in the Republic of Moldova. BMC Public Health. 2013;13:284.

15. Moreno-López D, Púa-Mora R. Servicios de salud amigables para adolescentes. Alemania: Una revisión de su implementación y principales características; 2012.

16. Moreno-López D. Progress of the Youth Friendly Health Services Model Implementation in Colombia. Presentation at the First International Forum of Adolescent Pregnancy Prevention, Bogotá D.C, Colombia; 2013

17. Profamilia. Encuesta Nacional de Demografía y Salud 2010, National Demographic and Health Survey 2010. Bogotá D.C: Asociación Probienestar de la Familia Colombiana; 2011

18. MacQuarrie K. Unmet Need for Family Planning among Young Women: A Global Comparison of Levels, Trends, and Components. DHS Comparative Reports No 34. Rockville: ICF International; 2014.

19. PAHO. Health in the Americas, 2007. Scientific and Technical Publication No. 622. Country Colombia. Vol. 2. pp. 225. Washington DC: Pan American Health Organization; 2007.

20. Colombia MSPS, UNFPA. Servicios amigables en salud para adolescentes y jóvenes. Un modelo para adecuar las respuestas de os servicios de salud a las necesidades de adolescentes y jóvenes de Colombia. Bogotá D.C. Colombia: Ministerio de Salud y Protección Social y Fondo de Población de las Naciones Unidas; 2007.

21. UNFPA. Compromiso de los partidos y movimientos políticos. Por la promoción y la garantía de los derechos humanos, sexuales y reproductivos. Bogotá D.C: UNFPA; 2011.

22. WHO. Nine steps for developing a scaling-up strategy. Geneva: World Health Organization; 2010.

23. Colombia MSPS. Manual de Normas Tecnicas. Normativa de Atencion al Adolescente. Colombia: Ministerio de Salud y Protección Social; 1993.
24. Colombia MSPS. Política Nacional de la Salud Sexual y Reproductiva. Bogotá D.C. Colombia: Ministerio de Salud y Protección Social; 2003.

25. Colombia MSPS. Resolución No 0425 del 2008 en Política Nacional de Salud 2007-2010. Bogotá D.C: Ministerio de Salud y Protección Social; 2008.

26. Fernández D. Lecciones aprendidas del proyecto del Fondo Mundial en Colombia. Bogotá D.C: Proyecto Colombia; 2007.

27. Valencia CP, Canaval GE, Molina AP, Caicedo HA, Serrano LM, Valencia R, et al. Servicios amigables para jóvenes: Construcción conjunta entre jóvenes y funcionarios. Health care services for young people: A joint construction among youth and health personnel. Colombia Médica. 2010;41:41.

28. Colombia MSPS, UNFPA. Evaluación sumativa de los Servicios de Salud Amigables para Adolescentes y Jóvenes en Colombia. Bogotá, D.C: Ministerio de Salud y Protección Social, UNFPA; 2011.

29. Colombia MSPS. Consolidado de Indicadores 2013, Servicios de Salud Amigable para Adolescentes y Jóvenes. 2014

30. UN. Population and Development: Programme of action adopted at the International Conference on Population and Development, Cairo, Depart. For Economic and Social Information and Policy Analysis; 1995. New York: United Nations; 2014. p. 193.

31. UN. Fourth World Conference on Women, Action for Equality, Development and Peace, Beijing China. Beijing: United Nations; 1995

32. Tylee A, Haller DM, Graham T, Churchill R, Sanci LA. Youth-friendly primary care services: How are we doing and what more needs to be done? Lancet. 2007:369(35):1565-73.

33. Toloza-Pérez DC. Este es tu centro, socio" Una experiencia exitosa de servicios de salud amigables para jóvenes en Bogotá, Colombia. 2013.

34. Colombia MSPS. La implementación de servicios de salud amigables para adolescentes y jóvenes en el departamento de Huila. La experiencia de las ESE de Campoalegre, La Plata y Neiva. Bogotá D.C. Bogotá D.C.: Ministerio de Salud y Protección Social; 2010.

35. Colombia MSPS. Informe de Actividades 2012-2013. Sector Administrativo de Salud y Protección Social al Honorable Congreso de la República. Bogotá D.C: Ministerio de Salud y Protección Social; 2013.

36. Colombia MSPS. Indicadores de productividad de los SSAAJ y reporte de las Direcciones Territoriales de Salud. Bogotá D.C: Ministerio de Salud y Protección Social; 2012.

37. Colombia MSPS, UNFPA. Avances en la implementación del modelo de servicios de salud amigables para adolescentes y jóvenes, Análisis y evaluación 2010. Bogotá D.C: Ministerio de Salud y Protección Social, Fondo de Población de las Naciones Unidas; 2011.

38. Colombia MSPS. Modelo de veeduría social juvenil a los servicios de salud amigables para adolescentes y jóvenes. Guía conceptual y metodológica. Bogotá D.C: Ministerio de Salud y Protección Social; 2014

39. Colombia MSPS, UNFPA. Abriendo caminos, Consejo Nacional y Consejos Regionales de juventud para la prevención del embarazo adolescente. Bogotá: MSPS, UNFPA; 2014.

40. Colombia MSPS. Convenio de Cooperación 363 de 2013. Fortalecimiento de las acciones de salud sexual y reproductiva y garantía de derechos sexuales y reproductivos. Bogotá D.C: Ministerio de Salud y Protección Social; 2013.

41. Pontificia Universidad Javeriana. Diplomado para la formación del recurso humano prestador de servicios de salud de, IPS públicas y privadas que atienden a niñas, niños y adolescentes según la definición de los perfiles y funciones de los profesionales requeridos para la aplicación del modelo de atención en los. SSAAJ. Informe Final. Colombia: Pontificia Universidad Javeriana; 2013.

42. Colombia MSPS. Servicios amigables con enfoque diferencial en nuestras comunidades indígenas. Bogotá D.C: Ministerio de Salud y Protección Social; 2013 